УДК 378.016:5]:004

(C) Прокопенко А.І., Житєньова Н.В., 2019

https://orcid.org/0000-0003-1792-9388

https://orcid.org/0000-0002-3083-1070

DOI: $10.34142 / 23128046.2019 .47 .08$

Прокопенко А. I., житсньова Н. В.

\title{
АНАЛІЗ СТАНУ ПІДГОТОВКИ МАЙБУТНІХ УЧИТЕЛІВ ПРИРОДНИЧО-МАТЕМАТИЧНИХ ДИСЦИПЛІН ДО ЗАСТОСУВАННЯ ВІЗУАЛІЗАЦІЇ У ПРОФЕСІЙНІЙ ДІЯЛЬНОСТІ
}

Основною ідеєю Концепиії сучасної украӥнської освіти є забезпечення ії якості відповідно до запитів споживачів освітніх послуг, вимог держави, міжнародних стандартів і суспільства. Однією з провідних тенденцій розвитку сьогоднішньої професійної освіти є підвищення уваги до питань підготовки кадрів якісно нового рівня, які здатні до професійної самореалізачії, саморозвитку, до творчого пошуку, до вміння використовувати нові педагогічні технології у майбутній діяльності. Вихідним пунктом у відповідній підготовиі майбутнього педагога $\epsilon$ забезпечення його готовності до дидактично зумовленого та педагогічно ефективного застосування інформаиійно-комунікаиійних технологій у професійній педагогічній діяльності. Сьогодні провідним освітнім трендом $є$ залучення технологій візуалізаиії в освітню практику. Відповідно до иьього метою статті є аналіз стану підготовки майбутніх учителів дисциплін природничо-математичного ичилу до запровадження технологій візуалізації у власну професійну діяльність. Згідно до мети було виокремлено задачі, які полягають в аналізі навчальних планів, іншого забезпечення та відповідної документації щзодо окресленого напряму з підготовки майбутніх педагогів природничо-математичного ииклу у вищих педагогічних закладах освіти щодо встановлення переліку навчальних дисциплін, у процесі вивчення яких відбувається окреслена підготовка, а також аналіз навчальних програм дисииплін, які існують у даному напрямі, стосовно забезпечення підготовки студентів до створення авторських та адаптації існуючих цифрових візуальних дидактичних засобів. У статі було використано загальнонаукові методи дослідження, такі як: аналіз наукових, педагогічних і психологічних прачь, інформачійних джерел з проблеми дослідження; систематизація поглядів і досягнень учених; синтез та узагальнення теоретичних положень. Здійснено огляд закладів вищої освіти стосовно зазначеної підготовки майбутніх педагогів. Проведене авторами дослідження дало підстави вважати необхідним внесення певних змін до процесу підготовки майбутніх вчителів природничо-математичних дисциллін до використання технологій візуалізаиії в професійній діяльності.

Ключові слова: підготовка майбутнього вчителя, компоненти 
готовності, природничо-математичні дисципліни, технології візуалізації, навчальний процес.

Prokopenko A. I., Zhytenova N. V. Analysis of the state of preparation of future teachers of natural and mathematical disciplines to apply visualization in the professional activities. The main idea behind the Concept of Contemporary Ukrainian Education is to ensure its quality in accordance with the demands of consumers of educational services, the requirements of the state, international standards and society. One of the leading tendencies in the development of today's professional education is to increase the attention to the issues of training of a qualitatively new level, which are capable of professional self-realization, selfdevelopment, creative search, and ability to use new pedagogical technologies in future activity. The starting point in the proper preparation of the future teacher is to ensure their own readiness for the didactically conditioned and pedagogically effective use of information and communication technologies in professional pedagogical activity. Today, the leading educational trend is to integrate visualization technologies into educational practice. Accordingly, the purpose of the article is to analyze the state of preparation of future teachers of the disciplines of the natural and mathematical cycle for the introduction of imaging technologies in their own professional activity. According to the purpose, the tasks, which consist in the analysis of curricula, other providing and corresponding documentation on the outlined direction of preparation for preparation of future teachers of natural and mathematical direction in higher pedagogical educational establishments in the course of preparation of the course, are being singled out. , as well as an analysis of the syllabuses of the disciplines that exist in this area, to ensure that students are prepared to create copyright and adaptations of existing digital visual didactic tools. The article used general scientific methods of research, such as, analysis of scientific, pedagogical and psychological works, information sources on the problem of research, systematization of the views and achievements of scientists, synthesis and generalization of theoretical positions. Higher education institutions have been reviewed for such training for future educators. The research conducted by the authors gave grounds to consider it necessary to make certain changes to the process of preparing future teachers of natural and mathematical disciplines for the use of visualization technologies in their professional activity.

Keywords: future teacher preparation, readiness components, natural and mathematical disciplines, imaging technologies, educational process.

Вступ. У сучасному суспільстві природничо-математична освіта виступає основною рушійною силою його розвитку і однією з ії̈ провідних тенденцій $є$ посилення уваги до проблеми підготовки кадрів якісно нового рівня, здатних до вміння застосувати нові педагогічні технології та нові освітні тренди у майбутній діяльності, до яких, безумовно, належать 
технології візуалізації. Вихідним пунктом у такій підготовці студентапедагога $\epsilon$ забезпечення його готовності до дидактично зваженого використання візуальних ресурсів та створення якісних візуальних засобів для їхнього подальшого застосування у професійній педагогічній діяльності. Для ефективного здійснення такої діяльності в реальних умовах школи підготовка майбутнього вчителя повинна починатися ще в освітній установі, де він отримує педагогічну професію. Окреслені аспекти показують, що підготовці студентів-педагогів у галузі застосування технологій візуалізації має приділятися достатня увага в період їхнього навчання. Проте сьогодні проявляється тенденція наростання розриву між запитами школи щодо наявності педагогічних кадрів, здатних реалізовувати вимоги сучасного суспільства, і готовністю випускників-педагогів до здійснення такої діяльності.

Підготовка майбутніх учителів у системі педагогічної освіти України базується на грунтовних доробках вітчизняних та зарубіжних учених у науково-педагогічній сфері. Психолого-педагогічним питанням щодо проблеми підготовки вчителів до впровадження нових інформаційних технологій навчання присвячені дослідження В. Бикова, Л. Білоусової, М. Жалдака, Ю. Жука, Н. Морзе, С. Ракова, Ю. Рамського, Ю. Тріуса та інших. Оптимальні способи організації навчального процесу 3 використанням комп'ютерних візуальних навчальних матеріалів запропоновані Л. Долінером, Н. Паком, Н. Семеновою, В. Стародубцевим та іншими. Створенню оригінальних прийомів комп'ютерної візуалізації навчального матеріалу, розробці нових методик ऑiі застосування для конкретних дисциплін присвячені роботи О. Мансурова, О. Соболєвої, Б. Стариченко, С. Шушкевич.

У працях В. Касторнової, І. Косенко, С. Лозовенко, С. Малкіної, Г. Некрасової, Л. Сидорової, А. Тумалева розглянуті питання навчання майбутніх педагогів, розробки мультимедійних навчальних матеріалів. Вивченню проблем, пов'язаних 3 підготовкою педагогічних кадрів до застосування технологій візуалізації у професійній діяльності, присвячені дослідження таких авторів, як: Л. Білоусової, Н. Білошапки, Д. Безуглого, О. Семеніхіної, А. Юрченко та інших.

Мета та завдання. Мета статmі полягає в аналізі стану підготовки майбутніх вчителів природничо-математичних дисциплін до застосування технологій візуалізації в професійній діяльності в практиці роботи вищих педагогічних закладів освіти. Відповідно до мети було окреслено наступні завдання: 
- $\quad$ проаналізувати навчальні плани 3 підготовки майбутніх учителів природничо-математичного напряму у вищих педагогічних закладах освіти щодо встановлення переліку навчальних дисциплін, у процесі вивчення яких здійснюється підготовка студентів до використання інформаційнокомунікаційних технологій у напрямі візуалізації навчального матеріалу;

проаналізувати навчальні програми відповідних дисциплін стосовно забезпечення підготовки студентів до створення авторських та адаптації існуючих цифрових візуальних дидактичних засобів.

Методи дослідження. Для вирішення поставлених завдань було використано в комплексі наступні методи дослідження: аналіз наукових, педагогічних і психологічних праць, інформаційних джерел 3 проблеми дослідження; систематизація поглядів і досягнень учених - для виявлення стану розробленості проблеми; синтез та узагальнення теоретичних положень, розкритих у науковій та навчально-методичній літературі.

Результати. Сьогодні здійснено низку наукових досліджень, присвячених підготовці майбутніх педагогів до застосування сучасних інформаційно-комунікаційних технологій у педагогічній діяльності за різними напрямами. Грунтовні положення щодо професійної підготовки вчителів математики та інформатики висвітлено в дослідженнях М. Жалдака (Zhaldak, 1989). Питанням розвитку IT-компетентності майбутніх учителів математики у процесі їх професійної підготовки присвячено праці О. Семеніхіної (Semenixina, 2018). Проблеми якісної професійної підготовки майбутніх учителів природничо-математичного напряму розглянуті у роботах О. Біляковської (Bilyakovska, 2017). У працях Н. Житєньової теоретично обгрунтовано сутність і структуру інформаційно-технологічної компетенції майбутнього вчителя, розроблено модель інформаційнотехнологічної компетенції майбутнього вчителя (Zhytienova, 2019). У дослідженнях Л. Білоусової та С. Криштоф детально розглянуто проблеми реалізації готовності майбутнього вчителя природничо-математичних дисциплін до використання інтернет-підтримки у практиці навчання (Bilousova \& Krishtof, 2012 ).

Нами у статті (Zhytienova, 2019) з'ясовано низку факторів, які визначають необхідність підготовки вчителів до використання технологій візуалізації, до яких віднесено: швидкоплинний розвиток технологій, які дозволяють створювати візуальний контент; застосування інструментів створення візуалізації спочатку у бізнес-структурах та інших сферах, а лише потім в освіті; створення таких інструментів не для освітніх потреб, що зумовлює необхідність їх адаптації до процесу навчання; стрімке оновлення 
інструментарію, що в освітній практиці наштовхується на необізнаність педагога 3 його технічними особливостями й дидактичним потенціалом.

Необхідно наголосити на тому, що аналізу стану підготовки майбутніх педагогів до застосування технологій візуалізації в педагогічній діяльності передував аналіз стану використання візуалізації у практиці шкільної освіти. Відповідно до чого нами було проведено анкетування, в якому брали участь понад 200 вчителів України. Проведений аналіз показав, що вчителі вважають використання візуалізації обов'язковим компонентом освітнього процесу, оскільки їі застосування має потужний вплив на його ефективність. Також було зафіксовано, що вчителі намагаються застосовувати візуальні засоби у власній діяльності, і загалом використовують готові шаблони, i одразу намагаються знайти відповідний візуальний контент, але існує певний відсоток учителів, які спочатку шукають цікавий матеріал, а потім адаптують його під власні педагогічні цілі i лише деякі педагоги намагаються створювати власні візуальні дидактичні матеріали. Педагоги зазначають, що їм бракує досвіду щодо застосування та створення таких засобів, акцентують увагу на відсутності методичних матеріалів щодо застосування програмних засобів та онлайн сервісів в освітньому процесі, застарілості наявного технічного обладнання, відсутності мотивації. 3 огляду на це, особливо гостро для них постає питання щодо дизайну та технології створення відповідних візуальних матеріалів, оскільки вони інтуїтивно використовують правила дизайну, або аналізують схожі приклади візуалізації і відтворюють аналогічні. Проте з'ясовано, що загалом педагоги готові до самовдосконалення і самостійно опановують тематичні Інтернетджерела, блоги, навчаються на онлайнових платформах (Zhytienova, 2019).

Нами було проведено моніторинг закладів освіти Україні, які здійснюють підготовку вчителів природничо-математичного напряму $\mathrm{i}$ 3'ясовано, що у такому напрямі працює потужна мережа освітніх закладів, серед яких є класичні університети, педагогічні університети, інститути та коледжі тощо, а саме: Бердянський державний педагогічний університет, Вінницький державний педагогічний університет імені Михайла Коцюбинського, Донбаський державний педагогічний університет, Дрогобицький державний педагогічний університет імені Івана Франка, Київський університет імені Бориса Грінченка, Криворізький державний педагогічний університет, Центральноукраїнський державний педагогічний університет імені Володимира Винниченка, Мелітопольський державний педагогічний університет, Національний педагогічний університет імені М. П. Драгоманова, Полтавський національний педагогічний університет імені В. Г. Короленка, Південноукраїнський національний педагогічний 
університет імені К. Д. Ушинського, Рівненський державний гуманітарний університет, Сумський державний педагогічний університет ім. А. С. Макаренка, Тернопільський національний педагогічний університет імені Володимира Гнатюка, Уманський державний педагогічний університет імені Павла Тичини, Харківський національний педагогічний університет імені Г. С. Сковороди, Чернігівський національний педагогічний університет імені Т. Г. Шевченка.

Аналіз навчальних планів та програм дозволив з'ясувати, що на факультеті фізико-математичної, комп’ютерної та технологічної освіти Бердянського державного педагогічного університету в курсі «Теорія та методика навчання математики» розглядаються питання використання інформаційно-комунікаційних технологій як засобу наочності шкільного курсу математики, у рамках теми «Використання інформаційнокомунікаційних технологій у вивченні математики»; у курсі «Методика і технології навчання математики», у рамках теми «Інформаційнокомунікаційні технології у навчанні математики в школі» розглядаються питання застосування комп'ютера для вивчення математики у школі. Проте такі питання є загальними і не дозволяють розкрити специфіку використання візуалізації. У курсах «Методика і технології навчання фізики» та «Теорія та методика навчання фізики» питання застосування комп'ютерних технологій для візуалізації навчального матеріалу взагалі не піднімаються, як не передбачено і підготовки студентів природничого напряму.

Природничо-географічний факультет та факультет математики, фізики i технологій Вінницького державного педагогічного університету імені Михайла Коцюбинського містить обов'язкові курси «Комп’ютерноорієнтовані технології навчання» та «Інформатика та інформаційні технології», в яких розглядаються питання застосування інформаційнокомунікаційних технологій в освітньому процесі закладу загальної середньої освіти, а також курс «Сучасні інформаційні технології та медіаосвіта»у рамках вибіркової дисципліни. Дані курси містять загальні питання щодо використання ІКТ у діяльності вчителя, але у курсі «Комп’ютерноорієнтовані технології навчання» розкриваються питання застосування IКТ у системі моніторингу результатів навчальної діяльності, розглядаються аспекти застосування електронних освітніх ресурсів, принципи їх розробки та вимоги до навчальних комп’ютерних засобів, висвітлюється використання веб-технологій у навчальному процесі закладів освіти. Проте у рамках даного курсу багато часу відводиться на організацію проектної та самостійної діяльності студентів за методикою Intel - навчання для майбутнього, і украй мало часу - на розробку та проектування електронних 
ресурсів освітнього призначення. Питання щодо створення та використання технологій візуалізації не піднімаються взагалі.

На фізико-математичному факультеті Донбаського державного педагогічного університету передбачено тільки вивчення курсу «Інформатика», у рамках якого вибірково розглядаються питання застосування інформаційно-комунікаційних технологій для навчання фізики та математики. Природничого напряму підготовки майбутніх вчителів не передбачено.

Більш грунтовно, щодо застосування інформаційно-комунікаційних технологій у професійній діяльності майбутнього педагога, здійснюється підготовка у Київському університеті імені Бориса Грінченка, де таку підготовку передбачено на всіх факультетах. Здійснюється вона при викладанні таких курсів як: «Інформатика і комп'ютерна техніка» та «Інформаційно-комунікаційні технології навчання, технічні засоби навчання». У межах даних курсів розглядаються питання ознайомлення студентів із основами сучасних інформаційних технологій, основними галузями застосування сучасних технічних засобів, нових інформаційних технологій у професійній діяльності, формування теоретичної бази знань у галузі інформатики і обчислювальної техніки та навичок роботи 3 ПК, застосування інформаційно-комунікаційних технологій у професійній діяльності вчителя. Проте використанню та створенню візуальних дидактичних засобів для освітніх цілей приділено не достатньо уваги.

У Південноукраїнському національному педагогічному університеті імені К. Д. Ушинського на природничому та фізико-математичному факультетах питання підготовки майбутніх вчителів до використання IКТ у майбутній професійній діяльності розглядаються на базі вибіркових навчальних дисциплін у рамках курсів «Інформаційні технології у професійній підготовці» та «Використання обчислювальної техніки в навчальному процесі». У межах окреслених курсів висвітлюються аспекти роботи з офісними програмами та загальні питання роботи з комп'ютерною технікою. Щодо використання візуалізації в діяльності вчителя, то такі моменти не розглядаються взагалі.

Сумський державний педагогічний університет ім. А. С. Макаренка готує вчителів природничо-математичних дисциплін на природничогеографічному та фізико-математичному факультетах. Загальні питання застосування комп'ютера у майбутній професійній діяльності розглядаються у рамках курсів «Вибрані питання методики навчання математики, фізики, хімії, біології та географії» в темі «Використання нових інформаційних технологій навчання». 
У Тернопільському національному педагогічному університеті імені Володимира Гнатюка відповідна підготовка відбувається на трьох факультетах: хіміко-біологічному, географічному та фізико-математичному. Варто звернути увагу на те, що в курсах обов'язкових дисциплін не передбачено навчання майбутніх учителів до використання комп'ютерних технологій, але у рамках вибіркових дисциплін запропоновано курси «Сучасні інформаційні технології» та «Інформаційно-технічні засоби навчання», де висвітлюються загальні питання щодо застосування IКТ.

Уманський державний педагогічний університет імені Павла Тичини здійснює підготовку майбутніх вчителів біології, хімії, географії, математики та фізики на природничо-географічному факультеті та факультеті фізики, математики та інформатики. Питання застосування IКТ в освітньому процесі загальноосвітньої школи розглядаються в обов'язковому курсі «ІК технології в галузі», а також в курсі «Комп'ютерні технології в хімії» у рамках вибіркової дисципліни. Дані дисципліни спрямовані на ознайомлення студентів 3 основами сучасних інформаційних технологій, основами застосування сучасних технічних засобів, нових інформаційних технологій у процесі навчання фахових дисциплін, формування теоретичної бази знань у галузі інформатики і обчислювальної техніки та навичок роботи з ПК.

Чернігівський національний педагогічний університет імені Т. Г. Шевченка здійснює підготовку педагогічних кадрів на природничоматематичному факультеті за напрямом географія, хімія, біологія, математика та фізика. Серед базових дисциплін передбачено курси «Інформатика i інформаційні технології» та «Комп'ютерні технології в навчанні хімії», а також вибіркові дисципліни - «Комп’ютерна хімія» та «Нові інформаційні технології в хімії». Дані курси спрямовані на розгляд загальних питань щодо застосування ІКТ у професійній діяльності та використання програмно-педагогічного забезпечення для підтримки вивчення хімії.

У Дрогобицькому державному педагогічному університеті імені Івана Франка майбутніх учителів природничо-математичного напряму готують на базі навчально-наукового інституту фізики, математики, економіки та інноваційних технологій, а також на біолого-природничому факультеті. У Криворізькому державному педагогічному університеті - на природничому та фізико-математичному факультеті. У Центральноукраїнському державному педагогічному університеті імені Володимира Винниченка - на природничо-географічному та фізико-математичному факультетах. У Мелітопольському державному педагогічному університеті - на природничо-географічному, хіміко-біологічному факультетах та на 
факультеті інформатики, математики та економіки. У Національному педагогічному університеті імені М. П.Драгоманова - на факультеті природничо-географічної освіти та екології та фізико-математичному факультеті. У Полтавському національному педагогічному університеті імені В. Г. Короленка - на природничому та фізико-математичному факультетах. У Рівненському державному гуманітарному університеті - на психолого-природничому, фізико-технологічному факультетах і факультеті математики та інформатики. Аналізуючи навчальні плани i програми дисциплін, нами було з'ясовано, що в даних закладах освіти питання використання інформаційно-комунікаційних технологій для підтримки навчання шкільних дисциплін даного напряму не розглядаються. Навички роботи з комп'ютером та можливості його застосування в навчальному процесі розглядаються лише для вчителів інформатики та математики окремими питанням в загальних темах.

У Харківському національному педагогічному університеті імені Г. С. Сковороди на природничому та фізико-математичному факультетах відбувається підготовка майбутніх учителів природничо-математичних дисциплін. В переліку обов'язкових дисциплінах вивчаються курси «Сучасні інформаційні технології», «Медіаосвіта», «Комп'ютерні технології в професійній діяльності», «Технології візуалізації». У рамках вибіркових курсів вивчаються дисципліни «Смарт-інструментарій сучасного педагога», «Інфографіка в педагогічній діяльності». Частково питання застосування IКТ в професійній діяльності розглядаються в декількох темах курсу методика навчання відповідних дисциплін.

Обговорення. Як свідчить проведене дослідження, у проаналізованих навчальних програмах передбачається вивчення загальних питань щодо використання інформаційно-комунікаційних технологій, розглядаються особливості роботи в офісних програмах, з мережею Інтернет, з програмним забезпеченням вузького спрямування, проте питання підготовки майбутнього вчителя до використання технологій візуалізації, а також створення авторських та адаптації існуючих цифрових візуальних дидактичних засобів і педагогічно зваженого їхнього використання взагалі не піднімаються.

Висновки. Вивчення навчальних планів, програм навчальних дисциплін, програм педагогічних практик, а також іншого навчальнометодичного забезпечення (конспектів лекцій, планів практичних, лабораторних, індивідуальних занять, завдань для самостійної роботи, тематики курсових робіт, матеріалів до контролю тощо) освітнього процесу у закладах вищої освіти педагогічного профілю України засвідчило 
відсутність у них належного висвітлення питань підготовки майбутніх учителів природничо-математичних дисциплін до використання технологій візуалізації у майбутній професійній діяльності. Аналіз опитувань учителів природничо-математичних дисциплін також засвідчує недостатню їх підготовленість до використання технологій візуалізації в освітньому процесі. Проте, сьогодні оволодіння технологіями візуалізації стає для сучасного вчителя природничо-математичних дисциплін обов'язковою умовою ефективності його професійної діяльності. Однак, використання такого потужного інструмента, як візуалізація, потребує грунтовної підготовки майбутнього вчителя в інформатично-технологічному, психолого-педагогічному, методично-операціональному аспектах, тому перспективним напрямом є розробка і запровадження в практику навчання студентів відповідних педагогічних спеціальностей навчального курсу, спрямованого на застосування технологій візуалізації та на створення авторських дидактичних візуальних засобів.

\section{ЛІТЕРАТУРА:}

Білоусова Л. І., Криштоф Л.Д. Компоненти підготовки вчителя до використання інтернетпідтримки у навчальному процесі. Педагогические науки. Проблемы подготовки специиалистов, Режим доступу: http://www.rusnauka.com/1_NIO_2012/Pedagogica/2_98499.doc.htm.

Біляковська О. Професійна підготовка майбутніх вчителів природничо-математичних дисциплін: якісний вимір. Збірник наукових працьь «Педагогічні науки». Вип.80. T. 2, 2017, С.125-129. Режим доступу: http://www.ps.stateuniversity.ks.ua/arkhivvidannya?id=84

Жалдак М. И. Система подготовки учителя к использованию информационной технологии в учебном процессе : дис. в форме науч. доклада д-ра пед. наук : спец. 13.00 .02 / Жалдак Мирослав Иванович ; АПН СССР ; НИИ содержания и методов обучения. М., 1989. 48 с. Библиогр.: С. 44-48.

Житєньова Н. В. Майстер-клас як ефективна форма підготовки майбутнього вчителя до застосування технологій візуалізації у предметно-професійній діяльності. Фізикоматематична освіта, 2019. Вип. 1(19). С. 55-61. Режим доступу: https://fmojournal.fizmatsspu.sumy.ua/journals/2019-v1-19/2019_1-19-Zhytienova_FMO.pdf DOI 10.31110/2413-1571-2019-019-1-009

Семеніхіна О. Шляхи формування і розвитку IT-компетентності фахівців у процесі їх професійної підготовки. Освіта. Інноватика. Практика, 2018. № 1 (4). С. 44-51.

Яциніна Н. О. Інформаційно-технологічна компетенція як необхідна складова підготовки сучасного вчителя. Наука і соціальні проблеми суспільства: освіта, культура, духовність : матеріали $V$ Міжнародної науково-практичної конференції (20-21 травня 2008 р.). Харківський національний педагогічний університет імені Г. С. Сковороди. Харків, 2008. Ч. 1. С. 440-442.

\section{REFERENCES:}

Bilousova, L. I. \& Krishtof L.D. (2012) Komponenty pidhotovky vchytelia do vykorystannia internet-pidtrymky u navchalnomu protsesi. [Components of teacher preparation for using online support in the learning process]. Pedagogicheskie nauki. Problemy 
http://www.rusnauka.com/1_NIO_2012/Pedagogica/2_98499.doc.htm. (in Ukrainian).

Bilyakovska, O. (2017) Profesiina pidhotovka maibutnikh vchyteliv pryrodnychomatematychnykh dystsyplin: yakisnyi vymir [Vocational training for future teachers of science and mathematics: a qualitative dimension]. Zbirnyk naukovykh prats «Pedahohichni nauky». Vol.80(2), P.125-129. Retrieved from http://www.ps.stateuniversity.ks.ua/arkhiv-vidannya?id=84 (in Ukrainian).

Zhaldak, M. I. (1989) Sistema podgotovki uchitelja k ispol'zovaniju informacionnoj tehnologii v uchebnom processe [The system of teacher training for the use of information technology in the educational process]: dis. $\mathrm{v}$ forme nauch. doklada d-ra ped. nauk : spec. 13.00.02. APN SSSR; NII soderzhanija i metodov obuchenija. M., 48 p.: p. 44-48. (in Russian)

Zhytienova, N. V. (2019) Maister-klas yak efektyvna forma pidhotovky maibutnoho vchytelia do zastosuvannia tekhnolohii vizualizatsii u predmetno-profesiinii diialnosti [Workshop as an effective form of future teacher preparation for the application of imaging technologies in the subject-professional activity]. Fizyko-matematychna osvita, Vol. 1(19). P. 55-61. Retrieved from URL: https://fmojournal.fizmatsspu.sumy.ua/journals/2019-v1-19/2019_1-19-Zhytienova_FMO.pdf DOI 10.31110/2413-1571-2019-019-1-009 (in Ukrainian).

Semenixina, O. (2018) Shliakhy formuvannia i rozvytku IT-kompetentnosti fakhivtsiv u protsesi yix profesiinoi pidhotovky [Ways of formation and development of IT-competence of specialists in the process of their professional training]. Osvita. Innovatyka. Praktyka, № 1 (4). S. 44-51. (in Ukrainian).

Yatsynina, N. O. (2008) Informatsiino-tekhnolohichna kompetentsiia yak neobkhidna skladova pidhotovky suchasnoho vchytelia [Information and technological competence as a necessary component of the modern teacher's training]. Nauka $i$ sotsialni problemy suspilstva: osvita, kultura, dukhovnist : materialy $V$ Mizhnarodnoyi naukovopraktychnoyi konferenciyi (20-21 travnya 2008 r.). Xarkivskyi natsionalnyi pedahohichnyi universytet imeni G. S. Skovorody. Xarkiv, Vol. 1. P. 440-442. (in Ukrainian).

\section{Інформація про авторів:}

Прокопенко Андрій Іванович:

ORCID: https://orcid.org/0000-0003-17929388, доктор педагогічних наук, професор, директор інституту інформатизації освіти Харківського національного педагогічного університету імені Г.С. Сковороди, вул. Алчевських, 29, м. Харків, Україна, 61002.

e-mail: andrew72@meta.ua

\section{Житсньова Наталя Василівна:}

ORCID: https://orcid.org/0000-0002-30831070, кандидат педагогічних наук, доцент, професор кафедри інформатики Харківського національного педагогічного університету імені Г.С. Сковороди, вул. Алчевських, 29, м. Харків, Україна, 61002.

\section{Information about the authors:}

\section{Prokopenko Andrii Ivanovych:}

ORCID: https://orcid.org/0000-0003-17929388, Dr. hab. in Pedagogy, Professor, Director of the Institute for Informatization of Educatoin, H. S. Skovoroda Kharkiv National Pedagogical University, Alchevskikh street, 29, Kharkiv, Ukraine, 61002.

e-mail: andrew72@meta.u

\section{Zhytenova Natalia Vasylivna:}

ORCID: https://orcid.org/0000-0002-3083$1070, \mathrm{PhD}$ in Pedagogy, Associate Professor, Professor of the Department of Informatics, H. S. Skovoroda Kharkiv National Pedagogical University, Alchevskikh street, 29, Kharkiv, Ukraine, 61002. 
Цитуйте цю статтю як: Прокопенко А.І., Житєньова Н.В. Аналіз стану підготовки майбутніх учителів природничо-математичних дисциплін до застосування візуалізації у професійній діяльності. Теорія та методика навчання та виховання. 2019. № 47. С. 89100.

DOI: $10.34142 / 23128046.2019 .47 .08$

Дата надходження статті до редакції: 19.11.2019

Стаття прийнята до друку: 29.11.2019 